\title{
Potential for Hydrocyanic Acid Poisoning of Livestock by Indiangrass
}

\author{
K.P. VOGEL, F.A. HASKINS, AND H.J. GORZ
}

\begin{abstract}
Hydrocyanic acid or prussic acid poisoning of livestock by sorghums [Sorghum bicolor (L.)Moench] and sudangrasses [Sorghum sudanese (Piper) Stapf] is caused by the digestive liberation of hydrocyanic acid (HCN) from the cyanogenic compound, dhurrin $[(S)$-p-hydroxymandelonitrile $\beta$-D-elucopyranoside] found in tissue of these plants. Recent research documented that dhurrin is also present in indiangrass [Sorghastrum nutans (L.) Nash] seedlings. The purpose of this study was to determine the hydrocyanic acid potential (HCN-p) of foraze from established stands of indlangrass. Five cultivars representative of indiangrass germplasm of the Great Plains were sampled during the growing season for 2 years from 2 sites in eastern Nebraska. The HCN-p of the indiangrass sampled in this study exceeded $750 \mathrm{mg}^{-1} \mathrm{~kg}$ dry wt. (dangerous level) only in spring when new growth was $20 \mathrm{~cm}$ tall or less. Levels were less than $500 \mathrm{mg}^{-1} \mathrm{~kg}_{\mathrm{g}}$ (safe) when new growth was at least $40 \mathrm{~cm}$ tall and were very low $\left(<200 \mathrm{mg}^{-1} \mathrm{~kg}\right)$ or not detected when the forage was over $1 \mathrm{~m}$ tall. Pure stands of indiangrass that are grazed when the new growth is less than $20 \mathrm{~cm}$ tall could be lethal to livestock.
\end{abstract}

Key Words: prussic acid, HCN, dhurrin, poisonous plants, Sorshastrum nutans

Dhurrin [ $(S)$-p-hydroxymandelonitrile $\beta$-D-glucopyranoside] was the first cyanogenic compound isolated from a Gramineae (Tjon Sie Fat 1977). It was isolated from sorghum [Sorghum bicolor (L.) Moench] plants in 1902 by Dunstan and Henry (1902). When hydrolyzed, dhurrin yields hydrocyanic acid (HCN), glucose, and $p$-hydroxybenzaldehyde (p-HB) in equimolar amounts. In young sorghum leaves, dhurrin is localized in vacuoles of epidermal cells while the enzymes responsible for the release of HCN from dhurrin are located in mesophyll cells (Kojima et al. 1979). This separation of enzyme and substrate probably accounts for the fact that in healthy, intact leaf tissue little, if any, free cyanide is present.

Authors are supervisory research geneticist, USDA-ARS; George Holmes professor of agronomy, Univ. of Nebraska; and supervisory research geneticist, USDAARS; Department of Agronomy, University of Nebraska, Lincoln, Nebr. 68583.

Contribution of the Agricultural Research Service, USDA and the Nebraska Agr. Res. Div., Lincoln. Published as Paper 8236, Journal Series, Nebraska Agr. Res. Div. Manuscript accepted 27 May 1987.
In ruminants, mastication and subsequent rumen digestion of sorghum and sudangrass [Sorghum sudanense (Piper) Stapf] result in release of $\mathrm{HCN}$. The released $\mathrm{HCN}$ is absorbed directly into the bloodstream from the rumen (Kingsbury 1964). The absorbed $\mathrm{HCN}$ inhibits cytochrome oxidase of the mitochzondrial respiratory system thus causing asphyxiation at the cellular level (Kingsbury 1964, Solomonsen 1981). Ingestion of a lethal dose can result in death within 15 minutes to a few hours (Kingsbury 1964). Boyd et al. (1938) listed the following relative toxicities of sorghum and sudangrass forage at various $\mathrm{HCN}$-p (hydrocyanic acid potential) levels (dry matter basis): 0 to $500 \mathrm{mg} \mathrm{kg}^{-1}$ was considered safe to utilize; 500 to $750 \mathrm{mg} \mathrm{kg}^{-1}$ was of doubtful toxicity; and above $750 \mathrm{mg} \mathrm{kg}^{-1}$ was dangerous to utilize as feed. Dhurrin concentration of sorghum leaves is highest at the seedling stage and decreases as the plant matures. Dhurrin is also present in high concentrations in herbage regrowth after harvest.

The presence of dhurrin in other grasses was not firmly established until Gorz et al. (1979) reported it in seedlings of indiangrass [Sorghastrum nutans (L.) Nash]. Subsequently, Haskins et al. (1979) screened 39 grass species representing 14 genera and 2 tribes (Andropogoneae and Tripsaceae) and found dhurrin only in seedlings of Sorghastrum nutans and Sorghastrum pellitum. A spectrophotometric assay for $\mathrm{HCN}$-p (Gorz et al. 1977) was used in these studies. This assay measured $p$-HB on the basis of its absorbance at 330nm. Since dhurrin degradation yields $\mathrm{HCN}$ and $p-\mathrm{HB}$ in equimolar amounts, $\mathrm{HCN}$-p values can be calculated from $p-\mathrm{HB}$ concentrations. Results of Haskins et al. (1979) indicated that the HCN-p of indiangrass seedling tissue exceeded the levels considered to be safe in sorghums and could be as high as $3,000 \mathrm{mg}^{-1} \mathrm{~kg}$ on a dry weight basis. Haskins et al. (1979) also sampled tillers of established indiangrass plants for HCN-p. Their preliminary results indicated that the tiller leaves did contain dhurrin, but it was apparent that interfering substances in the mature plant tissue were confounding the assay. The seedling assay has subsequently been modified for use on mature plant tissue (Haskins et al. 1984).

The purpose of this study was to determine the HCN-p of forage from established stands of indiangrass by using the spectrophoto-

JOURNAL OF RANGE MANAGEMENT 40(6), November 1987 
metric assay for mature tissue.

\section{Materials and Methods}

Forage of 5 indiangrass cultivars representative of the germplasm of the Great Plains was sampled during 2 years at 2 eastern Nebraska sites. The cultivars and their origin (Hanson 1972) were: 'Holt' (northeast Nebraska), 'Nebraska 54' (southeast Nebraska), 'Oto'(southeast Nebraska and northeast Kansas), 'Osage'(east and central Kansas and Oklahoma), and 'Llano'(eastern New Mexico). Sites were the University of Nebraska Agricultural Research and Development Center at Mead, Neb. (35 km west of Omaha, Neb.) and the Leonard Christian farm in Pawnee County, NE (120 km south of Omaha). The soil at Mead was a Sharpsburg silty clay loam (Typic Argiudoll) while the Pawnee County soil was a Pawnee clay loam (Aquic Argiudoll). Replicated variety trials which included the cultivars listed above and some experimental strains were seeded at Mead in 1980 and at the Pawnee site in 1981. The experimental design was a randomized complete block with 6 replicates. Plots were $4.3 \times 1.2 \mathrm{~m}$.

Forage aftermath from the previous growing season was removed by either mowing or burning prior to spring growth. The herbicides atrazine [6-chloro-N-ethyl-N'-(1-methylethyl)-1,3,5-triazine-2,4-diamine], alachlor [2-chloro- $\mathrm{N}$-(2,6-diethylphenyl)- $\mathrm{N}$-(methoxymethyl)acetamide], and 2,4-D [(2,4-dichlorophenoxy)acetic acid] were used alone or in combination for weed control. Herbicides and nitrogen fertilizer $\left(\mathrm{NH}_{4} \mathrm{NO}_{3}\right)$ were applied in either April or early May before the indiangrasses had initiated spring growth. Nitrogen and herbicide rates, given in $\mathrm{kg} \mathrm{ha}^{-1}$ for each locationyear, were: (1) Mead in 1983-N, 112; atrazine, 1.1; alachlor, 2.2. (2) Mead in 1984-N, 112; alachlor, 2.2; 2,4-D, 1.1. (3) Pawnee in 1983-N, 56; atrazine, 2.2; alachlor, 1.1. (4) Pawnee in 1984-N, 74; atrazine, 3.3 .

Three of the 6 replicates at each site were sampled for HCN-p in
1983 and 1984 at 3 different times during the growing season. In 1983, plots at Mead were sampled on $2 \mathrm{June}, 26 \mathrm{June}$, and 12 Aug., while in 1984 they were sampled on 25 June, 13 July, and 6 Aug. In both years the Pawnee plots were sampled either the day before or the day after the Mead plots. All harvests except for the first harvest in 1983 were made with a sickle bar mower at a cutting height of $5 \mathrm{~cm}$. A $0.6-\mathrm{m}$ wide swath was cut across the width of a plot. The forage was collected and subsampled to obtain a 250- to $300-g$ sample for analyses. An equivalent area was harvested with hand clippers for the first harvest in 1983. Subsequent harvests were from areas of the plots that had not been harvested previously. Yields were not determined. Plant height (maximum natural height of leaves or stems) at the sampling date was measured. Harvested samples were dried in a $70^{\circ} \mathrm{C}$ oven for 48 hours, and the dry forage was immediately ground to pass a $1-\mathrm{mm}$ screen. Subsamples of ground tissue were held in a freezer at about $-17^{\circ} \mathrm{C}$ until they were analyzed for $\mathrm{HCN}-\mathrm{p}$.

The HCN-p of the ground samples was determined by the spectrophotometric procedure described by Haskins et al. (1984) for mature sorghum leaves. In brief, portions of the dried, ground samples were autoclaved in water, a treatment which extracts dhurrin and breaks it down into its constituent parts, HCN, glucose, and $p-\mathrm{HB}$. The $p$-HB was then extracted with ether, diluted in $0.1 \mathrm{M} \mathrm{NaOH}$, and measured spectrophotometrically at $330 \mathrm{~nm}$. Calculations of HCN-p were on a dry weight basis. Samples also were analyzed for in vitro dry matter digestibility (IVDMD) (Tilley and Terry 1963) and crude protein [Kjeldahl $N \times 6.25$ (A.O.A.C. 1960)] to provide estimates of forage quality at the various sampling dates.

Analyses of variance procedures were used to analyze the data for a single harvest at a location and over locations for the same harvest.

Table 1. Mean hydrocyanic acid potential (HCN-p), height, dry matter, protein, and IVDMD values of 5 indiangrass cultivars at 3 harvests at 2 locations in eastern Nebraskn in 1983.

\begin{tabular}{|c|c|c|c|c|c|c|c|c|c|c|}
\hline \multirow[b]{2}{*}{ Cultivar } & \multicolumn{2}{|c|}{ HCN-p } & \multicolumn{2}{|c|}{ Height } & \multicolumn{2}{|c|}{ Dry matter } & \multicolumn{2}{|c|}{ Protein } & \multicolumn{2}{|c|}{ IVDMD } \\
\hline & Mead & Pawnee & Mead & Pawnee & Mead & Pawnee & Mead & Pawnee & Mead & Pawnee \\
\hline & \multicolumn{2}{|c|}{ mg kg ${ }^{-1}$ dry wt. } & & $\mathrm{cm}-$ & \multicolumn{2}{|c|}{-Harvest 1 (2 June)- } & & & & \\
\hline $\begin{array}{l}\text { Holt } \\
\text { Oto } \\
\text { Nebraska } 54 \\
\text { Osage } \\
\frac{\text { Llano }}{X} \\
\text { LSD } .05^{-}\end{array}$ & $\begin{array}{l}545 \\
855 \\
723 \\
582 \\
596 \\
660^{\cdots *} \\
91\end{array}$ & $\begin{array}{l}438 \\
666 \\
441 \\
407 \\
885 \\
568 \\
205\end{array}$ & $\begin{array}{l}24 \\
17 \\
25 \\
24 \\
15 \\
21 \\
\text { NS }\end{array}$ & $\begin{array}{l}19 \\
21 \\
21 \\
20 \\
21 \\
20 \\
\text { NS }\end{array}$ & $\begin{array}{l}35.4 \\
34.7 \\
35.3 \\
35.0 \\
27.7 \\
33.6^{* *} \\
\text { NS }\end{array}$ & $\begin{array}{l}22.6 \\
20.6 \\
21.7 \\
21.3 \\
21.7 \\
21.6 \\
\text { NS }\end{array}$ & $\begin{array}{l}17.1 \\
18.1 \\
17.0 \\
18.0 \\
18.9 \\
17.8 \approx \\
1.2\end{array}$ & $\begin{array}{r}20.1 \\
20.9 \\
20.6 \\
20.7 \\
19.2 \\
20.3 \\
\text { NS }\end{array}$ & $\begin{array}{l}66.8 \\
66.367 .7 \\
67.6 \\
66.7 \\
68.9 \\
67.2 \\
1.5\end{array}$ & \begin{tabular}{r|}
69.2 \\
\\
69.7 \\
68.0 \\
64.9 \\
67.9 \\
NS
\end{tabular} \\
\hline $\begin{array}{l}\text { Holt } \\
\text { Oto } \\
\text { Nebraska } 54 \\
\text { Osage } \\
\frac{\text { Llano }}{X} \\
\text { LSD.06 }_{.0}\end{array}$ & $\begin{array}{c}90 \\
146 \\
122 \\
127 \\
147 \\
126^{*} \\
22\end{array}$ & $\begin{array}{r}102 \\
118 \\
100 \\
116 \\
142 \\
115 \\
15\end{array}$ & $\begin{array}{l}65 \\
65 \\
65 \\
65 \\
65 \\
65 \\
\text { NS }\end{array}$ & $\begin{array}{l}65 \\
65 \\
65 \\
65 \\
65 \\
65 \\
\text { NS }\end{array}$ & $\begin{array}{l}\text { Harv } \\
21.0 \\
20.1 \\
19.9 \\
20.0 \\
18.8 \\
20.0 \\
1.4\end{array}$ & $\begin{array}{l}2 \text { (26 June)- } \\
21.3 \\
19.2 \\
19.9 \\
20.7 \\
19.4 \\
20.1 \\
1.3\end{array}$ & $\begin{array}{c}9.7 \\
11.9 \\
10.5 \\
12.6 \\
13.5 \\
11.6^{* *} \\
1.9\end{array}$ & $\begin{array}{r}9.6 \\
9.9 \\
9.6 \\
10.0 \\
10.6 \\
10.0 \\
\text { NS }\end{array}$ & $\begin{array}{l}61.6 \\
62.3 \\
62.6 \\
62.4 \\
63.3 \\
62.4 * * \\
\text { NS }\end{array}$ & $\begin{array}{r}58.5 \\
61.3 \\
63.4 \\
59.4 \\
58.5 \\
60.2 \\
\text { NS }\end{array}$ \\
\hline $\begin{array}{l}\text { Holt } \\
\text { Oto } \\
\text { Nebraska } 54 \\
\text { Osage } \\
\frac{\text { Llano }}{X} \\
\text { LSD.0s }_{.0}\end{array}$ & $\begin{array}{l}0 \dagger \\
0 \\
0 \\
0 \\
0 \\
0 \\
-\end{array}$ & $\begin{array}{l}0+ \\
0 \\
0 \\
0 \\
0 \\
0 \\
-\end{array}$ & $\begin{array}{r}138 \\
105 \\
118 \\
107 \\
108 \\
115 \\
10\end{array}$ & $\begin{array}{l}77 \\
83 \\
92 \\
88 \\
95 \\
87 \\
\text { NS }\end{array}$ & $\begin{array}{l}\text {-Harves } \\
38.3 \\
35.1 \\
38.5 \\
36.8 \\
32.9 \\
36.3^{* *} \\
2.9\end{array}$ & $\begin{array}{l}\text { (12 August) } \\
40.8 \\
41.0 \\
42.7 \\
45.4 \\
41.4 \\
42.3 \\
\text { NS }\end{array}$ & $\begin{array}{l}5.2 \\
5.0 \\
5.6 \\
5.6 \\
5.8 \\
5.5 \\
\text { NS }\end{array}$ & $\begin{array}{l}5.7 \\
5.1 \\
5.0 \\
4.8 \\
6.2 \\
5.3 \\
\text { NS }\end{array}$ & $\begin{array}{c}52.1 \\
54.1 \\
54.9 \\
55.6 \\
53.8 \\
54.1^{* *} \\
\text { NS }\end{array}$ & $\begin{array}{r}47.7 \\
47.4 \\
46.0 \\
45.1 \\
47.6 \\
46.8 \\
\text { NS }\end{array}$ \\
\hline
\end{tabular}

*** Indicates the location means are significantly different at the 0.05 or 0.01 levels of probability, respectively. NS indicates the $f$ test for cultivars was not significant.

$\uparrow \mathrm{HCN}-\mathrm{p} \leq 45 \mathrm{mg} \mathrm{kg}^{-1}$. 


\section{Results and Discussion}

In eastern Nebraska, indiangrass begins growth in late April to early May, and grazing of warm-season pastures or range containing indiangrass is normally initiated in mid- to late-June. The initial 1983 harvest was about 2 weeks prior to the start of the grazing season. The second harvest in 1983 and the first harvest in 1984 were approximately at the time grazing normally begins. The third harvest for both years occurred at the time when high quality warm-season hay should be harvested from ungrazed pastures. The second harvest in 1984 represented an intermediate stage of maturity.

Mean values for HCN-p, plant height, IVDMD, and protein for the samples collected in 1983 and 1984 are listed in Tables 1 and 2, respectively. Based on the toxicity ranges reported by Boyd et al. (1938) and listed above in the introduction, 1983 first-harvest forage from some of the cultivars at both Mead and Pawnee was potentially dangerous $\left(>750 \mathrm{mg} \mathrm{kg}^{-1}\right)$, but forage from the other 2 harvests in 1983 and from all three 1984 harvests was safe. During the 2-year period of the experiment, there were significant differences in HCN-p among cultivars for 6 of the 12 harvest-location combinations, but these differences were not consistent over locations or harvests. The primary factor affecting HCN-p of indiangrass herbage appears to be the stage of development of the plant with genotype or cultivar and environment having modifying effects. The cultivars used in this study represent materials initially collected from a broad array of sites in the Great Plains. It is reasonable to assume that similar HCN-p levels could be found in most indiangrass plants at similar stages of development.

Plant height has been used as a simple indicator of the stage at which sudangrasses and sorghum-sudangrass hybrids are safe to graze. Normally these summer annuals are safe to graze when the forage is at least $45 \mathrm{~cm}$ tall (Anderson and Guyer 1986). Our data indicate that plant height can also be used as an indicator of
$\mathrm{HCN}-\mathrm{p}$ in indiangrass. In pastures containing only indiangrass, HCN poisoning of livestock could occur in late spring and early summer if indiangrass is grazed when plants are less than $20 \mathrm{~cm}$ tall. Our data indicate, however, that pure stands of indiangrass are safe to graze when the grass is $\mathbf{4 0} \mathrm{cm}$ tall. Indiangrass in mixed stands in seeded pastures or in native rangelands would be diluted in the diet by other grasses and forbs, and the potential for $\mathrm{HCN}$ poisoning of livestock is thereby reduced. This type of dilution may account for the lack of reports of livestock death due to grazing indiangrass. Indiangrass is normally harvested for hay when it is 1 m or more in height; consequently, the possibility of $\mathrm{HCN}$ poisoning from indiangrass hay is remote. In forage sorghums and sudangrasses, stresses such as drought can result in elevated HCN-p levels (Harrington 1966). Under these conditions, increased HCNp of indiangrass forage would also be expected.

The protein and IVDMD of indiangrass, like $\mathrm{HCN}$-p, decreased as plants matured. Although there were differences among cultivars and locations for some of the harvests, these differences were not consistent. The protein content of the indiangrass forage that had potentially toxic levels of $\mathrm{HCN}$-p was $18 \%$ or higher. Values of IVDMD exceeding $60 \%$ were obtained for forages that differed greatly in HCN-p. Available data do not support the use of either protein content or IVDMD as indictors of $\mathrm{HCN}$-p. The spectrophotometric assay for $\mathrm{HCN}$-p is relatively fast and simple, and it can be done with standard laboratory equipment (analytical balance, autoclave, spectrophotometer). If there is any doubt about the toxicity of indiangrass forage, the forage should be analyzed for $\mathrm{HCN}-\mathrm{p}$.

\section{Literature Cited}

Anderson, B., and P. Guyer. 1986. Summer annual forage grasses. NebGuide G74-171. Coop. Ext. Serv., Univ. Nebraska.

Association of Omeial Agricultural Chemists. 1960. Official methods of analyses of the A.O.A.C. 9th ed. Ass. Off. Agr. Chem. Washington, DC.

Table 2. Mean hydrocyanic acid potential (HCN-p), height, dry matter, protein, and IVDMD values of 5 indiangrass cultivars at 3 harvests at 2 locations in eastern Nebraska in 1984.

\begin{tabular}{|c|c|c|c|c|c|c|c|c|c|c|}
\hline \multirow[b]{2}{*}{ Cultivar } & \multicolumn{2}{|c|}{ HCN-p } & \multicolumn{2}{|c|}{ Height } & \multicolumn{2}{|c|}{ Dry matter } & \multicolumn{2}{|c|}{ Protein } & \multicolumn{2}{|c|}{ IVDMD } \\
\hline & Mead & Pawnee & Mead & Pawnee & Mead & Pawnee & Mead & Pawnee & Mead & Pawnee \\
\hline & \multicolumn{2}{|c|}{ mg kg dry wt. } & & $\mathrm{cm}-$ & \multicolumn{4}{|c|}{$\%$} & & \\
\hline $\begin{array}{l}\text { Holt } \\
\text { Oto } \\
\text { Nebraska } 54 \\
\text { Osage } \\
\text { Llano } \\
X \\
\text { LSD }_{.06}\end{array}$ & $\begin{array}{r}113 \\
155 \\
210 \\
169 \\
184 \\
167 \\
20\end{array}$ & $\begin{array}{l}161 \\
146 \\
177 \\
196 \\
195 \\
175 \\
\text { NS }\end{array}$ & $\begin{array}{c}42 \\
35 \\
37 \\
35 \\
32 \\
36^{*} \\
5\end{array}$ & $\begin{array}{l}36 \\
39 \\
40 \\
40 \\
38 \\
39 \\
\text { NS }\end{array}$ & $\begin{array}{l}29.7 \\
27.6 \\
26.3 \\
28.0 \\
23.9 \\
27.1^{* *} \\
\text { NS }\end{array}$ & $\begin{array}{l}1 \text { (2 June)- } \\
25.6 \\
24.0 \\
24.7 \\
23.8 \\
22.8 \\
24.2 \\
\text { NS }\end{array}$ & $\begin{array}{l}11.6 \\
12.4 \\
13.8 \\
13.2 \\
12.9 \\
12.8^{*} \\
1.3\end{array}$ & $\begin{array}{r}12.8 \\
13.2 \\
14.4 \\
13.8 \\
13.5 \\
13.5 \\
\text { NS }\end{array}$ & $\begin{array}{l}67.1 \\
68.5 \\
69.6 \\
67.3 \\
67.3 \\
68.0^{*} \\
\text { NS }\end{array}$ & $\begin{array}{r}64.1 \\
64.1 \\
63.2 \\
63.1 \\
66.7 \\
64.2 \\
\text { NS }\end{array}$ \\
\hline $\begin{array}{l}\text { Holt } \\
\text { Oto } \\
\text { Nebraska } 54 \\
\text { Osage } \\
\frac{\text { Llano }}{X} \\
\text { LSD.06 }_{.0}\end{array}$ & $\begin{array}{l}84 \\
92 \\
80 \\
76 \\
88 \\
84^{* *} \\
\text { NS }\end{array}$ & $\begin{array}{c}114 \\
119 \\
103 \\
112 \\
107 \\
111 \\
\text { NS }\end{array}$ & $\begin{array}{l}66 \\
61 \\
65 \\
61 \\
52 \\
61 \\
\text { NS }\end{array}$ & $\begin{array}{l}58 \\
60 \\
64 \\
60 \\
61 \\
61 \\
N S\end{array}$ & $\begin{array}{l}\text {-Harv } \\
33.2 \\
33.5 \\
32.5 \\
31.7 \\
30.6 \\
32.3^{* *} \\
\text { NS }\end{array}$ & $\begin{array}{c}2 \text { (13 July) } \\
29.8 \\
29.8 \\
30.2 \\
28.2 \\
28.6 \\
29.3 \\
\text { NS }\end{array}$ & $\begin{array}{r}8.5 \\
8.0 \\
9.5 \\
9.1 \\
11.7 \\
9.4 \\
2.3\end{array}$ & $\begin{array}{r}10.1 \\
9.9 \\
9.4 \\
10.0 \\
9.6 \\
9.8 \\
\text { NS }\end{array}$ & $\begin{array}{r}59.7 \\
61.6 \\
61.6 \\
62.8 \\
64.1 \\
62.0 \\
\text { NS }\end{array}$ & $\begin{array}{r}59.6 \\
60.5 \\
61.0 \\
60.7 \\
66.1 \\
61.6 \\
1.9\end{array}$ \\
\hline $\begin{array}{l}\text { Holt } \\
\text { Oto } \\
\text { Nebraska } 54 \\
\text { Osage } \\
\frac{\text { Llano }}{X} \\
\text { LSD } .06\end{array}$ & $\begin{array}{l}135 \\
111 \\
110 \\
114 \\
108 \\
115^{* *} \\
9\end{array}$ & $\begin{array}{c}167 \\
154 \\
153 \\
140 \\
164 \\
156 \\
\text { NS }\end{array}$ & $\begin{array}{l}99 \\
83 \\
86 \\
83 \\
71 \\
85 \\
16\end{array}$ & $\begin{array}{r}91 \\
85 \\
105 \\
84 \\
87 \\
90 \\
\text { NS }\end{array}$ & $\begin{array}{l}\text { Harve } \\
39.2 \\
35.6 \\
36.9 \\
45.2 \\
31.0 \\
37.6^{*} \\
\text { NS }\end{array}$ & $\begin{array}{l}\text { (6 Augus } \\
42.8 \\
41.5 \\
39.0 \\
44.3 \\
42.6 \\
42.0 \\
\text { NS }\end{array}$ & $\begin{array}{l}5.9 \\
5.5 \\
5.3 \\
5.4 \\
7.4 \\
5.9 \\
\text { NS }\end{array}$ & $\begin{array}{l}5.8 \\
5.6 \\
4.8 \\
6.2 \\
5.9 \\
5.6 \\
\text { NS }\end{array}$ & $\begin{array}{c}51.3 \\
59.4 \\
56.6 \\
56.3 \\
60.9 \\
56.9 * * \\
4.4\end{array}$ & $\begin{array}{r}51.1 \\
53.9 \\
50.9 \\
53.8 \\
53.2 \\
52.6 \\
\text { NS }\end{array}$ \\
\hline
\end{tabular}

*** Indicates the location means are significantly different at the 0.05 and 0.01 levels of probability, respectively. NS indicates the f test for cultivars was not significant. 
Boyd, F.T., O.S. Anmodt, G. Bohstedt, and E. Truog. 1938. Sudan grass management for control of cyanide poisoning. J. Amer. Soc. Agron. 30:569-582.

Dunstan, W.R., and T.A. Henry. 1902. Cyanogenesis in plants II. The great millet Sorghum vulgare. Roy. Soc. London, Phil. Trans., Ser. A 199:399-410.

Gorz, H.J., W.L. Haas, J.E. Specht, and F.A. Haskins. 1977. Assay of p-hydroxybenzaldehyde as a measure of hydrocyanic acid potential in sorghums. Crop Sci. 17:578-582.

Gorz, H.J., F.A. Haskins, R. Dam, and K.P. Vogel. 1979. Dhurrin in Sorghastrum nutans. Phytochemistry 18:2024.

Hanson, A.A. 1972. Grass varieties in the United States. Agriculture Handbook No. 170. USDA-ARS. U.S. Government Printing Office, Washington, D.C.

Harrington, J.D. 1966. Hydrocyanic acid content of Piper, Trudan I, and 6 sorghum-sudangrass hybrids. Bull. 735, Pennsylvannia State Univ.
Haskins, F.A., H.J. Gorz, and K.P. Vogel. 1979. Cyanogenesis in indiangrass seedlings. Crop Sci. 19:761-765.

Haskins, F.A., H.J. Gorz, R.M. Hill, and J. Brakke Youngquist. 1984. Influence of sample treatment on apparent hydrocyanic acid potential of sorghum leaf tissue. Crop Sci. 24:1158-1163.

Kingsbury, J.M. 1964. Poisonous plants of the United States and Canada. Prentice-Hall, Inc., Englewood Cliffs, N.J.

Kojima, M., J.E. Poulton, S.S. Thayer, and E.E. Conn. 1979. Tissue distribution of dhurrin and of enzymes involved in its metabolism in leaves of Sorghum bicolor. Plant Physiol. 63:1022-1028.

Solomonson, L.P. 1981. Cyanide as a metabolic inhibitor. p. 12-28. In: B. Vennesland, E.E. Conn, C.J. Knowles, J. Westley, and F. Wissing (eds.) Cyanide in biology. Academic Press, New York.

Tilley, J.M.A., and R.A. Terry. 1963. A two-stage technique of the in vitro digestion of forage crops. J. British Grassl. Soc. 18:104-111.

Tjon Sie Fat, L. 1977. Contribution to the knowledge of cyanogenesis in argiosperms. 1. Communication. Cyanogenesis in some grasses. Proc. Koninkl. Nederl. Akad. Wetensch. 80:227-237. 